\title{
NEUROCOMPUTING FOR THE RESEARCH OF SUSTAINABLE REGIONAL DEVELOPMENT OF PHYSICAL CULTURE, SPORTS AND TOURISM IN THE CONTEXT OF ENSURING THE QUALITY OF HUMAN CAPITAL
}

\author{
Elena N. Letiagina, Valentina I. Perova, Alexander V. Gutko \\ Lobachevsky State University of Nizhny Novgorod, Russia
}

\begin{abstract}
In today's world, human capital is one of the key indicators of a country's sustainable socioeconomic development. We have used neurocomputing tools to study the current state of physical education, sports and active tourism in the context of ensuring the quality of human capital, in order to preserve the population's health and increase life expectancy. The relevance of research in this field is determined by the importance of physical activity for the development of human capital, which is one of the central internal factors of countries' economic potential. Human capital also plays an important role in ensuring national security and sustainable regional development. We have performed a cluster analysis of physical culture and sports data in Russian regions using the tools of neural networks, one of the branches of artificial intelligence. The proposed approach based on neurocomputing and neural network modeling can be helpful in informing strategy proposals and measures aimed at enhancing the sustainable development and the role of physical culture, sports and tourism to ensure the quality of human capital.
\end{abstract}

Keywords: physical culture, sport, human capital, tourism, neurocomputing, neural networks, cluster analysis.

\section{Introduction}

In today's world, one of the key indicators of a country's sustainable socio-economic development is human capital (Lonska and Mietule, 2015; Kuznetsov, 2012; Liu, 2015; Visvizi and Daniela, 2019). The quality of human capital is increasingly influenced by physical culture and sports (Abelkalns at al., 2014; Letiagina, Grinevich, Gutko, 2019), which are effective resources for economic development in different countries (Beutler, 2008). At the same time, the steady and healthy development of the sports 
industry can promote regional sustainable development (Yang, Xu, Yang, 2020).

Russian economy's innovative development requires a qualitative leap in the recognition of the importance of the human capital's role in the socio-economic activities of its regions and the country as a whole. One of the characteristics of human capital is a healthy lifestyle of a country's citizens, which ensures longevity of its population. In this regard, it is important to create the necessary conditions for the development of physical culture and sports in order to engage various segments of the population in mass physical culture and sports activities on a regular basis (Letiagina and Kolodeev, 2021; Letiagina, Perova, Orlova, 2019).

It should be noted that physical culture and sports not only promote the population's health by improving its physical development level, but they also serve to develop mental activity (Gorbunov and Dubrovsky, 2002), thus improving the quality of human capital.

Based on the data of the Ministry of Sports of the Russian Federation (Ministry of Sport of the Russian Federation, 2019), Figure 1 shows the engagement in physical culture and sports activities of the population aged 3 to 79 in Russia's federal districts in 2019.

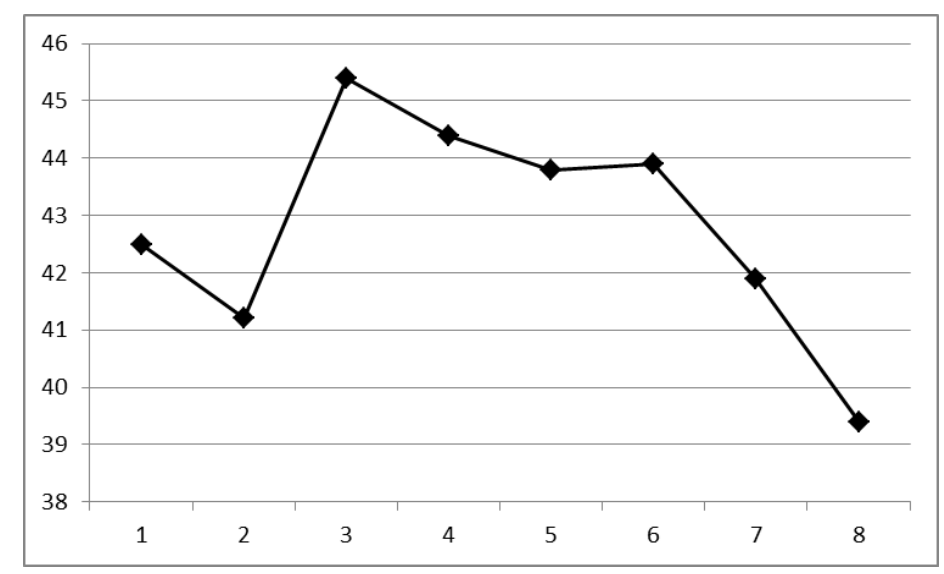

Figure 1. Population aged 3 to79 in Russia's federal districts engaged in physical culture and sports in 2019, \%: 1 - Central Federal District, 2 - Northwestern Federal District, 3 - Southern Federal District, 4 North Caucasian Federal District, 5 - Volga Federal District, 6 - Urals Federal District, 7 - Siberian Federal District, 8 - Far Eastern Federal District

Competitiveness enhancement in the field of physical culture and sports and the preparation of highly qualified athletes are among the priority areas for the development of physical culture, sports and active tourism in the Russian regions. These priority areas include: 
a) involving as many people as possible in systematic physical culture and mass sport activities;

b) further development of the infrastructure of physical culture, sports and active tourism using public-private partnerships;

c) development of the sports reserve and top performance sport;

d) improvement of the Human resource policy (HR policy) in the field of physical culture and sports.

In this regard, a cluster analysis of the development of physical culture and sports in Russian regions in the context of improving the quality of human capital is particularly appropriate.

\section{Materials and method}

In this paper, in the context of ensuring the quality of human capital, we study the activities of Russian regions in the field of physical culture and sports, based on the statistical data of the Russian Ministry of Sports for 2019. (Ministry of Sport of the Russian Federation, 2019):

$\mathrm{X} 1$ - number of sports facilities per 100 thousand people, (units);

$\mathrm{X} 2$ - percentage of the standard unit capacity of sports facilities (\%);

X3 - share of people who practise physical culture, sports and active tourism (aged 3 - 79 years) (\%);

$\mathrm{X} 4$ - staff (persons);

$\mathrm{X} 5$ - athletes who received sporting titles and categories (persons);

X6 - total expenditures on physical culture and sports (thousand roubles).

These indicators characterize the effectiveness of Russia's regions in the field of physical culture and sports.

To study how regional clusters are formed in relation to physical culture and sports, we used in this paper an innovative approach - artificial intelligence, namely, neural networks as one of its branches. A particular type of neural networks, Kohonen self-organising maps (SOMs) (Kohonen, 1982; Kohonen, 1990), was chosen for the study. This type was chosen because of the following features of such neural networks (Perova and Perova, 2018; Letiagina, et al., 2020; Carboni, Russu, 2015): a) there are no model limitations when analysing multidimensional statistical data; b) SOMs do not require any external intervention in the learning process; c) their learning algorithms allow projecting multidimensional input data space with the account of topology into either two-dimensional space or into three-dimensional space. This enables visualisation of the results obtained. In addition to visualisation, self-organising maps provide for efficient implementation of data clustering with the use of information technology. 
Data clustering is the partitioning of a set of objects (in our case, the regions of the Russian Federation) into clusters representing compact areas. When dividing a set of objects into clusters (providing a clustering solution), the following conditions must be met (Balabanov, Strongina, 2004):

- each object can only belong to one cluster;

- objects within one cluster are similar to each other in terms of the indicators under consideration;

- objects from different clusters are essentially dissimilar.

\section{Results \& Discussion}

In this paper, the clustering of raw data based on neural network modeling was carried out using Kohonen SOMs implemented in the Deductor analytical package.

As a result of neural network modelling, Russian regions in 2019 were distributed into five clusters. The number of Russian regions in such clusters is shown in Table 1.

Table 1. Number of Russian Federation regions in regional clusters

\begin{tabular}{|l|c|c|c|c|c|}
\hline Cluster & No. 1 & No. 2 & No. 3 & No. 4 & No. 5 \\
\hline Number of regions & 4 & 41 & 25 & 8 & 7 \\
\hline Number of regions, \% & 4.7 & 48.2 & 29.4 & 9.4 & 8.2 \\
\hline
\end{tabular}

The data in Table 1 show that there is a significant differentiation of regions by clusters. At the same time, it is important to note that the indicators studied had a different impact on the formation of regional clusters (Table 2).

Table 2. Significance of indicators in forming regional clusters, $\%$

\begin{tabular}{|l|c|c|c|c|c|}
\hline \multirow{2}{*}{ Indicator } & \multicolumn{5}{|c|}{ Cluster number } \\
\cline { 2 - 6 } & $\mathbf{1}$ & $\mathbf{2}$ & $\mathbf{3}$ & $\mathbf{4}$ & $\mathbf{5}$ \\
\hline $\mathrm{X} 1$ & 82.6 & 96.3 & 2.7 & 100 & 85.5 \\
\hline $\mathrm{X} 2$ & 74.3 & 91.8 & 100 & 38.7 & 99.9 \\
\hline $\mathrm{X} 3$ & 31.8 & 56.1 & 99.8 & 88.8 & 100 \\
\hline $\mathrm{X} 4$ & 53.8 & 92.1 & 63.7 & 100 & 67.2 \\
\hline $\mathrm{X} 5$ & 65.1 & 98.0 & 41.8 & 100 & 85.2 \\
\hline $\mathrm{X} 6$ & 100 & 98.2 & 86.7 & 99.0 & 41.5 \\
\hline
\end{tabular}


The composition of regional clusters in 2019 is presented in Table 3.

Table 3. Composition of regional clusters

\begin{tabular}{|l|l|}
\hline Cluster & Regions \\
\hline No. 1 & $\begin{array}{l}\text { Nenets Autonomous District, Vologda region, Karachay-Cherkessia } \\
\text { Republic, Chechen Republic. }\end{array}$ \\
\hline No. 2 & $\begin{array}{l}\text { Bryansk region, Ivanovo region, Kostroma region, Kursk region, Orel } \\
\text { region, Ryazan region, Smolensk region, Tver region, Yaroslavl region, } \\
\text { Komi Republic, Arkhangelsk region, Kaliningrad region, Leningrad } \\
\text { region, Murmansk region, Republic of Kalmykia, Astrakhan region, } \\
\text { Republic of Dagestan, Kabardino-Balkar Republic, Stavropol region, } \\
\text { Republic of Mari El, Udmurt Republic, Perm region, Kirov region, Nizhny } \\
\text { Novgorod region, Samara region, Saratov region, Khanty-Mansiysk } \\
\text { Autonomous District - Yugra, Republic of Altai, Republic of Khakassia, } \\
\text { Krasnoyarsk region, Novosibirsk region, Omsk region, Tomsk region, } \\
\text { Republic of Buryatia, Republic of Sakha (Yakutia), Kamchatka krai, } \\
\text { Primorsky krai, Amur region, Magadan region, Sakhalin region, Chukotka } \\
\text { Autonomous District. }\end{array}$ \\
\hline No. 3 & $\begin{array}{l}\text { Belgorod region, Vladimir region, Voronezh region, Kaluga region, } \\
\text { Lipetsk region, Tambov region, Tula region, Republic of Karelia, } \\
\text { Novgorod region, Pskov region, Republic of Adygea, Volgograd region, } \\
\text { Republic of Mordovia, Republic of Tatarstan, Chuvash Republic, } \\
\text { Orenburg region, Penza region, Ulyanovsk region, Kurgan region, } \\
\text { Tyumen region, Yamalo-Nenets Autonomous District, Republic of Tyva, } \\
\text { Altai krai, Kemerovo region, Khabarovsk krai. }\end{array}$ \\
\hline No. 4 & $\begin{array}{l}\text { Moscow region, Moscow, St. Petersburg, Krasnodar region, Rostov region, } \\
\text { Republic of Bashkortostan, Sverdlovsk region, Chelyabinsk region. }\end{array}$ \\
\hline No. 5 & $\begin{array}{l}\text { Republic of Crimea, Sevastopol, Republic of Ingushetia, Republic of North } \\
\text { Ossetia-Alania, Zabaykalsky krai, Irkutsk region, Jewish Autonomous } \\
\text { region. }\end{array}$ \\
\hline
\end{tabular}

Table 4 provides statistics on the average values of the considered indicators of physical culture and sports development for individual clusters and the overall average indicators for Russia.

It follows from the data in Table 4 correlating with the data in Table 2 that:

1. The indicators "Number of sports facilities per 100 thousand people" (X1), "Share of people who practise physical culture, sports and active tourism (aged 3-79 years)" (X3) and "Athletes who received sporting titles and categories" (X5) exceed their national average values in the regions of clusters No. 3 and No. 4.

2. The indicator "Percentage of the standard unit capacity of sports facilities" (X2) exceeds the national average values in the regions of cluster No. 3.

3. The "Staff " indicator (X4) is higher than the national average in the regions of Cluster 
4. The indicator "Total expenditures on physical culture and sports" (X6) exceeds the national average values in the regions of clusters No. 1 and No. 4.

It should be noted that in the regions of cluster No. 2 the values of the indicators are below the average for the Russian Federation.

Table 4. Average indicators for clusters and overall average indicators for the Russian Federation

\begin{tabular}{|l|l|c|c|c|c|c|c|}
\hline \multirow{2}{*}{ Year } & \multirow{2}{*}{$\begin{array}{l}\text { Cluster } \\
\text { number }\end{array}$} & \multicolumn{6}{|c|}{ Average values } \\
\cline { 3 - 8 } 2019 & 1 & $\mathbf{X 1}$ & $\mathbf{X 2}$ & $\mathbf{X 3}$ & $\mathbf{X} 4$ & $\mathbf{X 5}$ & $\mathbf{X 6}$ \\
\cline { 2 - 8 } & 2 & 2797 & 53.456 & 40.971 & 3347 & 9698 & 4935637.77 \\
\cline { 2 - 8 } & 3 & 3823 & 71.732 & 45.664 & 3536 & 16898 & 4672985.71 \\
\hline 4 & 11840 & 54.762 & 45.15 & 18900 & 47472 & 21838600.33 \\
\hline & 5 & 1784 & 37.296 & 28.257 & 2318 & 4912 & 6013379.12 \\
\cline { 2 - 8 } & $\begin{array}{l}\text { Average for } \\
\text { the Russian } \\
\text { Federation }\end{array}$ & 3797 & 57.4 & 42 & 4734 & 14819 & 8798974.73 \\
\hline
\end{tabular}

\section{Conclusions}

The sustainable regional development of physical culture, sports and tourism have a global transformative impact on the development of territories and the quality of life of the population. We have study the activities of Russian regions in the field of physical culture and sports, used an innovative approach - artificial intelligence. By applying the cluster analysis method based on neural network modelling to study the activities of Russian regions in the field of physical culture and sports, we have simulated five clusters that have similar or comparatively favourable conditions for sustainable regional development of physical culture, sports and tourism in the context of ensuring the quality of human capital. We have revealed marked differences in the size of clusters, which reflects the ametric nature of Russian regions' activities in this field. The regions that are promising in the development of physical culture and sports in terms of the indicators studied have been identified. These are the regions mainly in clusters No. 3 and No. 4 showing the highest indicator values: Moscow, St. Petersburg, Krasnodar region, Republic of Karelia, Novgorod region, Republic of Tatarstan, Tyumen region, Yamalo-Nenets Autonomous District, Altai krai, Kemerovo region, Khabarovsk krai and others. 
The results of our research have practical relevance and can be used in the strategic planning of regional development in the field of physical culture and sports for future periods. This will contribute to an increase in human capital, one of the priority internal factors of Russia's economic potential.

\section{References}

Abelkalns, I., Golubeva, A., Klempere-Sipjagina A. (2014). Studies of sport and health education teachers in the University of Latvia in the opinion of graduates. Society, integration, education, vol. 3, pp. 357-366.

Balabanov, A. S., Strongina, N. R. (2004). Data analysis in economic applications: Tutorial. Nizhny Novgorod: UNN Publishing House, 135 p.

Beutler I. (2008). Sport serving development and peace: Achieving the goals of the United Nations through sport. Sport in society, 11, 4, 359-369.

Carboni, O. A., Russu P. (2015). Assessing Regional Wellbeing in Italy: An Application of Malmquist-DEA and Self-Organizing Map Neural Clustering. Social Indicators Research, 122(3), 677-700. URL: https://doi.org/10.1007/s11205-014-0722-7

Gorbunov, S. A., Dubrovsky, A. V. (2002). The role of physical culture in improving mental readiness for learning and professional activity. Theory and practice of physical culture, 12, 13-15 (in Russ.).

Kohonen, T. (1990). The Self-Organizing Map. Proceedings of the Institute of Electrical and Electronics Engineers, 78(9), 1464-1480. URL: https://doi.org/10.1109/5.58325

Kohonen, T. (1982). Self-Organized Formation of Topologically Correct Feature Maps. Biological Cybernetics, 43(1), 59-69. URL: https://doi.org/10.1007/BF00337288

Kuznetsov, Yu. A. (2012). Human capital, labour productivity and economic growth. Economic analysis: Theory and practice, 43 (298), 2-14 (in Russ.).

Letiagina, E., Perova, V., Orlova, E. (2019). Neural network analysis of the development of physical education and sports in Russia as an economic factor of country security. Proceedings of the $4^{\text {th }}$ International Conference on Innovations in Sports, Tourism and Instructional Science (ICISTIS 2019). Atlantis Press, 11, 174-179, doi: https://doi.org/ 10.2991/icistis-19.2019.37

Letiagina, E. N., Grinevich, J. A., Gutko, A. V. (2019) Ways to improve the competitiveness of higher education programsweb of science, Human, technologies and quality of education, 62-66, DOI: 10.22364/HTQE.2019.06.

Letiagina, E. N., Perova, V. I., Gutko, A. V., Orlova, E. A. (2020). Research of youth sports in the Russian Federation as a factor of human capital formation using neural networks, Human, technologies and quality of education, 179-186, DOI: 10.22364/ htqe.2020.16.

Letyagina, E. N., Kolodeev, E. P. (2021). Problems of organizing and conducting online classes in physical culture and sports in educational organizations. Scientific notes of the P. F. Lesgaft University, 2 (192), 151-156, doi: 10.34835/issn.23081961.2021.2.p151-156 (in Russ.).

Liu, K. (2015). Research of investment in human capital in a sports club. International Journal of Simulation: Systems, Science and Technology, 16, 5A, 19.1-19.5. 
Lonska, J., Mietule, I. (2015). The impact of human capital development on the economic and social development of a country: Empirical study. Tehnologija. Resursi Environment, Technology, Resources: 10th International Scientific Practical Conference on Environment. Technology. Resources; Rezekne; Latvia, 2, 174-180.

Ministry of Sport of the Russian Federation. (2019). Доклад о реализации Стратегии развития физической культуры и спорта в Российской Федерации на период до 2020 года. (Report on the implementation of the Strategy for the Development of Physical Culture and Sports in the Russian Federation for the period up to 2020). Retrieved from: http://www.minsport.gov.ru.

Perova, V. I., Perova, N. A. (2018). Neural network modelling of the dynamics of physical culture and sports development in the regions of Russia as a factor of the country's socio-economic growth. National Interests: Priorities and Security, 14(11), 2064-2082. URL: https://doi.org/10.24891/ni.14.11.2064 (in Russ.).

Visvizi, A., Daniela, L. (2019). Technology-enhanced learning and the pursuit of sustainability. Sustainability, 11(15). URL: https://doi.org/ 10.3390/su11154022.

Yang, S. X., Xu, J. F., Yang, R. Y. (2020). Research on coordination and driving factors of sports industry and regional sustainable development-empirical research based on panel data of provinces and cities in Eastern China. Sustainability, 12(3). URL: https:// doi.org/ 10.3390/su12030813. 